\title{
Impact of percentage and particle size of sugarcane biochar on the sorption behavior of clomazone in Red Latosol
}

\author{
MARCOS R.F. DA SILVA ${ }^{1}$, MARIA ELIANA L.R. DE QUEIROZ ${ }^{1}$, ANTÔNIO A. NEVES ${ }^{1}$, ANTÔNIO A. \\ DA SILVA ${ }^{2}$, ANDRÉ F. DE OLIVEIRA ${ }^{1}$, RENAN L. DE OLIVEIRA ${ }^{1}$ and MARIANE M. AZEVEDO ${ }^{1}$ \\ ${ }^{1}$ Laboratório de Química Analítica/LAQUA, Departamento de Química, Universidade Federal de Viçosa, \\ Avenida Peter Henry Rolfs, s/n, Campus Universitário, 36570-900 Viçosa, MG, Brazil \\ ${ }^{2}$ Laboratório de Manejo Integrado de Plantas Daninhas/MIPD, Departamento de Fitotecnia, Universidade \\ Federal de Viçosa, Avenida Peter Henry Rolfs, s/n, Campus Universitário, 36570-900 Viçosa, MG, Brazil
}

Manuscript received on February 2, 2018; accepted for publication on June 8, 2018

\begin{abstract}
Biochar is a carbonaceous material that has excellent potential as a fertilizer and soil conditioner. However, there is a lack of information concerning the effects of the amount and particle size of this pyrogenic material on the soil sorption capacity. In this work, evaluation was made of changes in clomazone (CMZ) sorption in a Red Latosol following soil conditioning using different percentages $(0.25,0.5$, and $1 \%$ $\mathrm{w} / \mathrm{w})$ of sugarcane biochar in three particle sizes $(<106,106-508$, and 508-610 $\mu \mathrm{m})$. The conditioned soils presented apparent sorption coefficients $\left(\mathrm{K}_{\mathrm{d}}\right)$ up to 1300 times higher than that of pure soil, besides changes in the behavior of CMZ sorption. The biochar particle size and percentage influenced sorption of the herbicide as well as its retention in the amended soil during desorption processes. Both sorption and desorption Freundlich constants were linearly correlated with the external surface area of the biochar present in the soil.
\end{abstract}

Key words: Apparent sorption coefficient, batch experiment, external surface area, factorial design, Freundlich isotherm, herbicide retention.

\section{INTRODUCTION}

The Terras Pretas de Índio (TPI) are highly fertile soils that occur in small areas of the Amazon region (Glaser and Birk 2012, Rittl et al. 2015, Schmidt et al. 2014). The presence of organic matter from pyrogenic origins is one of the main factors responsible for the advantageous physical characteristics, structure, and fertility of these soils (Benites et al. 2009). The use of biochar to mimic

Correspondence to: Maria Eliana Lopes Ribeiro de Queiroz E-mail:meliana@ufv.br the TPI has shown satisfactory results in terms of the retention and availability of nutrients in the soil, since these materials have large surface areas and high ion exchange capacities, and also provide an additional source of nutrients (Glaser et al. 2002, Petter and Madari 2012, Wu et al. 2017, Zhao et al. 2017).

The feasibility of using biochar as a soil conditioner is of considerable interest to Brazilian agroindustry, which generates a large quantity of organic waste that often has no suitable destination. The sugar and alcohol industry is especially 
notable in this respect, since it produces around 200 million tons of organic waste annually. These wastes are often burned in furnaces at the industrial installations, in order to avoid transportation costs (IPEA 2012). The use of the pyrolyzed solid waste in sugarcane crop production would make the production process more sustainable, as well as help to reduce environmental contamination by pesticides. The use of pesticides in the production of this crop accounts for approximately $7.5 \%$ of the 914,200 tons of these substances consumed in Brazilian plantations (in 2014), with the great majority being herbicides (Scorza Júnior 2009, SINDIVEG 2015). This makes sugarcane cultivation the second largest consumer of these agricultural inputs (SINDIVEG 2015).

Clomazone (CMZ, Table I), a selective herbicide that belongs to the isoxazolidinone chemical group, is one of the active ingredients applied for weed control in sugarcane crops. The compound is absorbed by the roots and is transported through the plants in the xylem, and shows higher efficiency when applied preemergence (MAPA 2013). Its activity is related to the inhibition of carotenoid production, which leads to the loss of chlorophyll, since in the absence of carotenoids, chlorophyll is more readily degraded by photooxidation processes (Silva et al. 2007).

The high solubility of CMZ in water $(1102 \mathrm{mg}$ $\mathrm{L}^{-1}$ at $20^{\circ} \mathrm{C}$ ) can lead to potential negative impacts on groundwater. Its half-life has been found to vary between 79 and 124 days, depending on the composition of the soil, so its moderate persistence can affect successive crops in the same area. In addition, CMZ is a non-dissociable compound that presents high volatility $\left(19.2 \mathrm{mPa}\right.$ at $\left.25^{\circ} \mathrm{C}\right)$ (IUPAC 2007, Van Scoy and Tjeerdema 2014).

The addition of biomass charcoal to soil alters the sorptive capacity, leading to greater retention of pesticides and potentially reducing environmental contamination. Conditioning of soil with bamboo biochar was found to result in greater sorption of the herbicide pentachlorophenol in the soil, hence reducing the contamination of soil and groundwater through leaching of the herbicide (Xu et al. 2012). The incorporation of wheat straw biochar in soil increased hexachlorobenzene sorption 42-fold, compared to soil without addition of biochar, and reduced dispersion of the herbicide (Song et al. 2012).

Although it is known that biochar can assist in mitigating pesticide contamination of soil, greater understanding is required of its properties in terms of sorptive capacity and the mechanisms of sorption of chemicals in the soil. The objective of this study was to evaluate the influence of the addition of sugarcane biomass biochar, in different percentages and particle sizes, on the retention of CMZ in soil. Investigation was made of the behavior of CMZ sorption, as well as in the changes of physicochemical characteristics of the soil amended with biochar.

\section{EXPERIMENTAL}

\section{CHEMICALS}

The chemicals used were clomazone $(98.1 \% \mathrm{w} / \mathrm{w})$ and HPLC grade acetonitrile (Sigma-Aldrich, Seelze, Germany), dihydrated calcium chloride and sodium azide (Vetec, Rio de Janeiro, Brazil), and deionized water purified using a Millipore system.

A stock $1000 \mathrm{mg} \mathrm{L}^{-1}$ standard solution of CMZ was prepared by dilution in acetonitrile. The working solutions used in the sorption tests were prepared by diluting the stock solution with a previously prepared solution containing $\mathrm{CaCl}_{2}$ (1.11 $\mathrm{mg} \mathrm{L}^{-1}$, employed to simulate the ionic strength of soil solutions) and $\mathrm{NaN}_{3}\left(250 \mathrm{mg} \mathrm{L}^{-1}\right.$, used to inhibit microbial activity).

\section{SOIL COLLECTION AND BIOCHAR PRODUCTION}

A Red Latosol with low organic matter content was collected at 0-20 cm depth, in an area without recent history of herbicide application, in the municipality 
TABLE I

Physicochemical properties of Clomazone (CMZ).

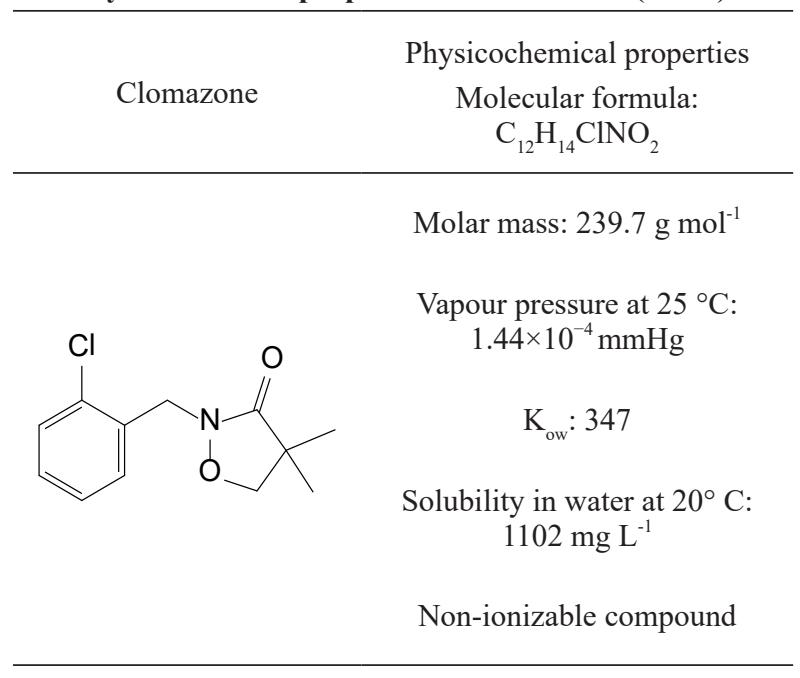

of Tangará da Serra in Mato Grosso State (latitude $14^{\circ} 39^{\prime} 4.01$ ' S, longitude $57^{\circ} 26^{\prime} 0.64$ ” W). The soil was air dried and sieved through a $2 \mathrm{~mm}$ mesh, and was subsequently characterized (EMBRAPA 1997). The physicochemical characteristics of the soil are presented in Table II.

The sugarcane biomass (with $60 \%$ moisture content) was dried for $48 \mathrm{~h}$ at $60{ }^{\circ} \mathrm{C}$ in a forced air circulation drying oven. The dried material was chopped in a disintegrator and then pyrolyzed at 400 ${ }^{\circ} \mathrm{C}$ for $6 \mathrm{~h}$ under a $\mathrm{CO}_{2}$ atmosphere in a laboratory muffle furnace. The resulting biochar was milled, dried at $60{ }^{\circ} \mathrm{C}$ for $12 \mathrm{~h}$, and sieved through different meshes, yielding three fractions with particle sizes of $610-508,508-106$, and $<106 \mu \mathrm{m}$, which were used to investigate the influence of particle size on the CMZ sorption processes in the soil. The biochars were mixed with soil and homogenized to obtain amended soils with biochar in different particle sizes and percentage. The physicochemical characteristics of the soil amended using 1\% (w/w) biochar with particle size $<106 \mu \mathrm{m}$ are shown in Table II.

\section{HPLC ANALYSES}

The chromatographic analyses were performed on an HPLC system (Shimadzu, Tokyo, Japan) equipped with an LC-20AT pump, a SIL-10AF autosampler, a CTO-10ASVP oven, and an SPD$20 \mathrm{~A} \mathrm{UV} / \mathrm{Vis}$ detector set at $210 \mathrm{~nm}$.

The chromatographic separation was performed using a Shimadzu C18 column (VPODS, $150 \times 4.6 \mathrm{~mm}, 4.6 \pm 0.3 \mu \mathrm{m}$ ) maintained at 30 ${ }^{\circ} \mathrm{C}$. Isocratic elution was performed with a mobile phase composed of acetonitrile and deionized water $(40: 60, \mathrm{v} / \mathrm{v})$, at a flow rate of $1.2 \mathrm{~mL} \mathrm{~min}^{-1}$. The injected sample volume was $20 \mu \mathrm{L}$ and the retention time was $12.4 \mathrm{~min}$. Quantification of $\mathrm{CMZ}$ was performed by the external standards method. The Limit of detection (LOD) and quantification (LOQ) were determined using blank soil solution (solution containing $1.11 \mathrm{mg} \mathrm{L}^{-1} \mathrm{CaCl}_{2}$ and $250 \mathrm{mg}$ $\mathrm{L}^{-1} \mathrm{NaN}_{3}$ stirred with a soil sample for $24 \mathrm{~h}$ ). They were estimated based on a signal-to-noise ratio $(\mathrm{S} / \mathrm{N})$ of 3 and 10 for LOD and LOQ, respectively. The accuracy and precision were evaluated using blank solutions fortified with $0.25,5.0$ and $15 \mathrm{mg}$ $\mathrm{L}^{-1}$ (in triplicate) through a recovery test and the relative standard deviation (RSD), respectively, as suggested by ANVISA (2017).

\section{Effect of particle size and biochar percentage on sorption/desorption of CMZ in the soil}

A $2^{2}$ factorial design with 3 replications at the central point was employed to investigate the combined effects of biochar particle size and biochar/soil percentage $(\%, w / w)$ on the retention and behavior of CMZ in the soil. Table III shows the particle sizes and biochar/soil percentages evaluated, together with the coded values. These percentages are equivalent to $1.25,2.5$ and 5 tons biochar $\mathrm{ha}^{-1}$, considering the application of biochar in the first $5 \mathrm{~cm}$-layer of soil.

Sorption tests were used to obtain the apparent sorption coefficient $\left(K_{d}^{\text {sor }}\right)$, adopted as the response in the factorial design. 
TABLE II

Physicochemical characteristics of soil (S) and soil amended by $1 \%$ of biochar in particle size $<106 \mu \mathrm{m}(\mathrm{S}+\mathrm{B})$.

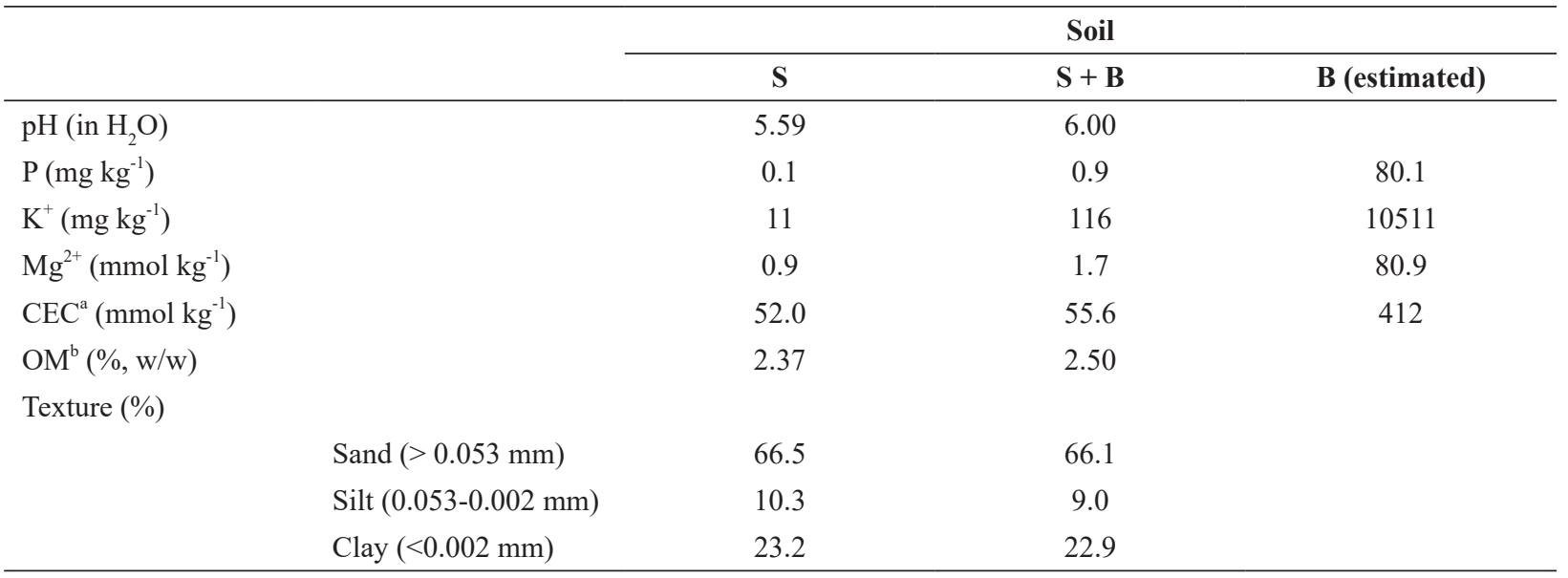

${ }^{a} \mathrm{CEC}$ - Cationic Exchange Capacity at $\mathrm{pH} 7$.

${ }^{\mathrm{b}} \mathrm{OM}$ - Organic Matter.

Analyses carried out in the Laboratório de Análise de Solo, Tecido Vegetal e Fertilizante from Universidade Federal de Viçosa, according to the methodology of Empresa Brasileira de Pesquisa Agropecuária-EMBRAPA.

CLOMAZONE SORPTION/DESORPTION TESTS IN SOIL AMENDED WITH BIOCHAR

\section{Sorption equilibrium time}

The assays were carried out based on Procedure 106 (Batch Equilibrium) of the Organization for Economic Co-operation and Development (OECD 2000).

Firstly, it was necessary to determine the time required for $\mathrm{CMZ}$ to reach sorption equilibrium in the soil. This was achieved using soil samples amended with $1 \%(\mathrm{w} / \mathrm{w})$ of biochar with particle size $<106 \mu \mathrm{m}$, and in the absence of biochar. The soil/solution ratio was 1:5 (w/v), and CMZ solutions were prepared in the presence of calcium chloride $\left(1.11 \mathrm{mg} \mathrm{L}^{-1}\right)$ and sodium azide $(250 \mathrm{mg}$ $\left.\mathrm{L}^{-1}\right)$ to inhibit microbiological activity.

The time required for equilibrium sorption of $\mathrm{CMZ}$ was determined by suspending $2.00 \mathrm{~g}$ portions of soil in $10.0 \mathrm{~mL}$ volumes of a solution containing $\mathrm{CaCl}_{2}\left(1.11 \mathrm{mg} \mathrm{L}^{-1}\right), \mathrm{NaN}_{3}(250 \mathrm{mg}$ $\left.\mathrm{L}^{-1}\right)$, and $\mathrm{CMZ}\left(10.0 \mathrm{mg} \mathrm{L}^{-1}\right)$, in glass centrifuge tubes. The suspensions were maintained under horizontal stirring (180 rpm) for periods of up to
$32 \mathrm{~h}$, at constant temperature $\left(21^{\circ} \mathrm{C}\right)$, followed by centrifugation at $1300 \mathrm{xg}$ for $5 \mathrm{~min}$. Aliquots of the supernatants were filtered using syringe filters containing $0.45 \mu \mathrm{m}$ PTFE membranes, and were then analyzed using HPLC.

The concentrations of CMZ in the soil $\left(C_{s}^{\text {sor }}\right.$, $\left.\mathrm{mg} \mathrm{kg}^{-1}\right)$ after different stirring times were calculated from the difference between the initial $\left(C_{0}\right)$ and final $\left(C_{a q}^{s o r}\right)$ concentrations in the aqueous solution (mg $\left.\mathrm{L}^{-1}\right)$ :

$$
C_{s}^{\text {sor }}=\frac{V_{0}}{m_{\text {soil }}} x\left(C_{0}-C_{a q}^{\text {sor }}\right)
$$

where $m_{\text {soil }}(\mathrm{kg})$ is the mass of soil (or soil amended with biochar) and $V_{0}(\mathrm{~L})$ is the volume of $\mathrm{CMZ}$ solution added to the soil.

The data were analyzed using one-way analysis of variance (ANOVA) and the post-hoc Tukey test, adopting a $95 \%$ confidence level. The $C_{s}^{\text {sor }}$ values were plotted against time (h) and the equilibrium time was defined as the point at which the sorption values reached a plateau (OECD 2000).

The pseudo-first order, pseudo-second order, and Elovich models were applied in order to 
TABLE III

Experiments of factorial design $2^{2}$ with center points employed to evaluate the factors particle size and biochar percentage on sorption and behavior of $\mathrm{CMZ}$ into soil amended with biochar.

\begin{tabular}{ccccc}
\hline & \multicolumn{2}{c}{ Encoded factors } & \multicolumn{2}{c}{ Original factors } \\
\hline Experiments & F(1) & F(2) & Particle Size $(\mathbf{1}) /(\boldsymbol{\mu m})$ & Percentage (2) /(\%) \\
\hline E1 & - & - & $<106$ & 0.25 \\
E2 & + & - & $508-610$ & 0.25 \\
E3 & - & + & $<106$ & 1 \\
E4 & + & + & $508-610$ & 1 \\
E5* & 0 & 0 & $106-508$ & 0.5 \\
\hline
\end{tabular}

*These experiments were carried out in triplicate, E5 is equivalent to center point of factorial design.

evaluate the effect of biochar addition on the kinetics of CMZ sorption in the soil. The pseudofirst order model is given by:

$q_{t}=q_{\theta}\left(1-e^{-k_{1} t}\right)$

where $q_{\theta}\left(\mathrm{mg} \mathrm{kg}^{-1}\right)$ and $q_{t}\left(\mathrm{mg} \mathrm{kg}^{-1}\right)$ are the amounts absorbed at equilibrium and at a given time $t$, respectively, and $k_{l}\left(\mathrm{~h}^{-1}\right)$ is the rate constant (Janos et al. 2007, Plazinski et al. 2009, Qiu et al. 2009).

The pseudo-second order model is described by the following linear equation (Janos et al. 2007):

$\frac{t}{q_{t}}=\frac{1}{k_{2} q_{\theta}^{2}}+\frac{t}{q_{\theta}}$

where the rate constant $\left(k_{2}, \mathrm{mg} \mathrm{kg}^{-1} \mathrm{~h}^{-1}\right)$ and $q_{\theta}$ $\left(\mathrm{mg} \mathrm{kg}^{-1}\right)$ are obtained from the slope and intercept, respectively, of a plot of $t / q_{t}$ against $t(\mathrm{~h})$ (Peruchi et al. 2015, Plazinski et al. 2009, Qiu et al. 2009).

The Elovich model (Eq. 4), which was originally proposed for describing the adsorption of gases in solid systems, can also be used to describe the removal of pollutants from aqueous solutions (Qiu et al. 2009). Use of this model is restricted to the beginning of the sorption process, since it neglects the simultaneous occurrence of desorption, when the sorption process is at equilibrium (Plazinski et al. 2009). In this model, the intercept $\left(1 / Y \ln (X Y), \mathrm{mg} \mathrm{kg}^{-1}\right)$ represents the amount sorbed during the initial stage of the sorption process, corresponding to the fast adsorption step, due to movement of the adsorbate to the most accessible part of the sorbent, while the slope $\left(1 / Y, \mathrm{mg} \mathrm{kg}^{-1} \mathrm{~h}^{-1}\right)$ is related to the second slow sorption stage and to the duration of this process $(\ln t)$ (Fernández-Bayo et al. 2008, Peruchi et al. 2015).

$q_{t}=\frac{1}{Y} \ln (X Y)+\frac{1}{Y} \ln t$

\section{Sorption assays}

The sorption tests used to investigate the effects of particle size and biochar percentage on the retention and behavior of $\mathrm{CMZ}$ in the soil were also based on the Batch Equilibrium procedure (OECD 2000).

In the experiments based on the factorial design, the apparent sorption coefficients $\left(K_{d}^{\text {sor }}\right)$ were determined using a $10.0 \mathrm{mg} \mathrm{L}^{-1} \mathrm{CMZ}$ solution containing $\mathrm{CaCl}_{2}\left(1.11 \mathrm{mg} \mathrm{L}^{-1}\right)$ and $\mathrm{NaN}_{3}(250 \mathrm{mg}$ $\left.\mathrm{L}^{-1}\right)$. Volumes of $10.0 \mathrm{~mL}$ of this solution were added to glass centrifuge tubes containing $2.00 \mathrm{~g}$ of the soil samples (as indicated in the factorial design), and the suspensions were stirred for a period corresponding to the previously established equilibrium time. After this period, the tubes were centrifuged and the supernatants were filtered and analyzed by HPLC. The same procedure was performed (in triplicate) using the soil without 
biochar, for use as a reference in comparison of the results. The apparent sorption coefficients were calculated using Eq. 5:

$K_{d}=\frac{C_{s}}{C_{a q}}$

where $C_{s}\left(\mathrm{mg}_{\mathrm{CMZ}} \mathrm{kg}_{\text {soil }}{ }^{-1}\right)$ is the concentration of the sorbed compound and $C_{a q}\left(\mathrm{mg}_{\mathrm{CMZ}} \mathrm{L}_{\text {aqueous solution }}{ }^{-1}\right)$ is the concentration of herbicide present in solution, at equilibrium (MacKay and Vasudevan 2012). The data analysis was performed with Statistica v. 8 software (StatSoft, Tulsa, USA).

Sorption isotherms were obtained for the factorial design experiments and also for soil without biochar. Five different $\mathrm{CMZ}$ concentrations were added $\left(10,12.5,15,17.5\right.$, and $\left.20 \mathrm{mg} \mathrm{L}^{-1}\right)$ in $2.00 \mathrm{~g}$ portions of the soil samples described in the factorial design, as well as made to determine the $K_{d}^{a d s}$ values.

The results were fitted using the Freundlich model (Eq. 6), which describes the relation between the amount of the compound present in solution $\left(C_{a q}\right.$, in $\left.\mathrm{mg} \mathrm{L}^{-1}\right)$ and the amount sorbed in the soil $\left(C_{s}\right.$, in $\left.\mathrm{mg} \mathrm{kg}^{-1}\right)$, at equilibrium.

$$
C_{s}^{s o r}(e q)=K_{f}^{s o r} C_{a q}^{s o r}(e q)^{\frac{1}{n}}
$$

The Freundlich constant $\left(K_{f}^{\text {sor }}\right.$, in $\left.\mathrm{mg}^{1-1 / \mathrm{n}} \mathrm{L}^{1 / \mathrm{n}} \mathrm{kg}^{-1}\right)$ is a parameter that characterizes the soil sorption capacity for a given compound (Wu et al. 2011).

\section{Desorption assays}

The desorption tests were performed as a continuation of the sorption assays. In this procedure, all the remaining supernatant in the samples from the sorption test was removed. Subsequently, the volume of solution removed was replaced by an equal volume of solution containing $\mathrm{CaCl}_{2}$ and $\mathrm{NaN}_{3}$ (without CMZ). The samples were then subjected to the same stirring, centrifugation, and filtration procedure used in the sorption assays, and aliquots of the final supernatants were analyzed by HPLC. The data obtained were used to determine $K_{d}^{\text {des }}$ and $K_{f}^{\text {des }}$, provided by the Freundlich desorption isotherms.

\section{Estimation of biochar external surface area}

The external surface areas of environmental solid particles can be estimated based on their geometric shape, density $\left(\rho, \mathrm{g} \mathrm{cm}^{-3}\right)$, and diameter $(\mathrm{d}, \mu \mathrm{m})$. Assuming spherical shape of the biochar particles, their external areas $\left(A_{e x t}, \mathrm{~m}^{2} \mathrm{~g}^{-1}\right)$ could be calculated according to Eq. 7 (Papelis et al. 2003, Schmukat et al. 2012). The total area of the biochar ( $A_{\text {tot.biochar }}$, $\mathrm{m}^{2}$ ), could then be obtained by multiplying $A_{\text {ext }}$ by the mass of the adsorbent $\left(m_{\text {biochar }}, \mathrm{g}\right)$ employed in each experiment of the factorial design, as shown in Eq. 8.

$A_{\text {ext }}=\frac{6}{d x \rho}$

$A_{\text {tot.biochar }}=\frac{6 \times m_{\text {biochar }}}{d x \rho}$

The value of $m_{\text {biochar }}$ was obtained by multiplying the percentage of biochar in the amended soil $(\%$ biochar, \% $\mathrm{w} / \mathrm{w})$ by its mass $\left(m_{\text {soil }+ \text { biochar }}, \mathrm{g}\right)$, as shown in Eq. 9.

$m_{\text {biochar }}=\%$ biochar $x m_{\text {soil }+ \text { biochar }} \times 100$

Substituting $m_{\text {biochar }}$ in Eq. 8 resulted in Eq. 10 . Since the biochars used in the experiments had the same density (constant $\rho$ ), given that they originated from a single sample, $A_{\text {tot.biochar }}$ was dependent on the ratio between \% biochar and the particle diameter $d$, as shown in Eq. 11 .

$$
\begin{aligned}
& A_{\text {tot.biochar }}=\frac{6 x m_{\text {biochar }}}{d x \rho}=\frac{6 \times \% \text { biochar } x m_{\text {soil }+ \text { biochar }} \times 100}{d x \rho} \\
& A_{\text {tot.biochar }}=\frac{k x \% \text { biochar }}{d} \quad k=\frac{6 x m_{\text {soil }+ \text { biochar }} \times 100}{\rho}
\end{aligned}
$$

As $A_{\text {tot.biochar }}$ was proportional to the ratio $\%$ biochar $/ d\left(\mu \mathrm{m}^{-1}\right)$, determination was made of the correlations between \% biocharld and $K_{f}^{\text {sor }}$ and 
$K_{f}^{\text {des }}$, as well as between $\%$ biochar/d and the $1 / n$ parameters obtained in the sorption and desorption isotherms, in order to evaluate the influence of $A_{\text {tot. }}$ biochar on these parameters.

\section{RESULTS AND DISCUSSION}

METHOD FOR DETERMINATION OF CMZ IN SOIL SOLUTIONS

The identification of CMZ was performed by comparing the retention time of the analyte in a fortified extract with the retention time $\left(\mathrm{R}_{\mathrm{t}}=\right.$ $12.4 \mathrm{~min}$ ) for a standard solution of the herbicide prepared in acetonitrile. The selectivity was confirmed by comparing the chromatograms for an extract obtained by stirring soil (amended using 1\% biochar with particle size $<106 \mu \mathrm{m}$ ) with a $20 \mathrm{mg}$ $\mathrm{L}^{-1} \mathrm{CMZ}$ solution (previously prepared in a solution containing $1.11 \mathrm{mg} \mathrm{L}^{-1} \mathrm{CaCl}_{2}$ and $250 \mathrm{mg} \mathrm{L}^{-1} \mathrm{NaN}_{3}$ ) and an extract obtained using the same procedure, but without CMZ (Figure 1).

$\mathrm{CMZ}$ was quantified by the external standards method. The LOD and LOQ were found to be 0.006 and $0.019 \mathrm{mg} \mathrm{L}^{-1}$. The analytical curve was obtained by analyzing solutions containing the herbicide at concentrations between 0.025 and $20 \mathrm{mg} \mathrm{L}^{-1}$, together with $1.11 \mathrm{mg} \mathrm{L}^{-1} \mathrm{CaCl}_{2}$ and $250 \mathrm{mg} \mathrm{L}^{-1} \mathrm{NaN}_{3}$. The curve showed a correlation coefficient $(r)$ of 0.9998 , indicative of low dispersion of the experimental data and low uncertainty of the regression equation, confirming that the analytical technique enabled reliable quantification of CMZ (ANVISA 2003). The precision of the method (expressed as the RSD) was $1.6 \%, 5.2 \%$ and $0.5 \%$, and the accuracy (expressed as the average recoveries) was $111 \%, 103 \%$ and $99 \%$ at concentration levels $0.25,5.0$ and $15 \mathrm{mg}$ $\mathrm{L}^{-1}$, respectively.

\section{EQUILIBRIUM TIME}

The soils with addition of biochar (at $1 \%$, using the biochar with particle size $<106 \mu \mathrm{m})$ and without

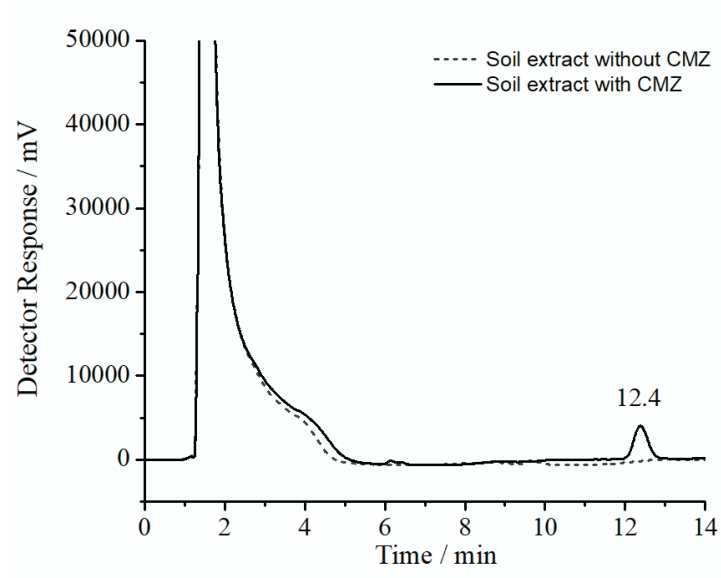

Figure 1 - Chromatograms of extracts of soil amended with $1 \%$ biochar in particle size $<106 \mu \mathrm{m}$ : (---) obtained in a 20 mg L ${ }^{-1} \mathrm{CMZ}$ solution (prepared $\mathrm{CaCl}_{2} 1.11 \mathrm{mg} \mathrm{L}^{-1}$ and $\mathrm{NaN}_{3}$ $250 \mathrm{mg} \mathrm{L}^{-1}$ ); (---) obtained in $\mathrm{CaCl}_{2}$ and $\mathrm{NaN}_{3}$ solution without herbicide. The samples of soil amended with biochar were placed under stirring for $24 \mathrm{~h}$ with these solutions.

biochar addition were stirred with a $10 \mathrm{mg} \mathrm{L}^{-1}$ CMZ solution for different periods up to $32 \mathrm{~h}$ (Figure 2). It was found that after $2 \mathrm{~h}$ of stirring, the concentrations of CMZ in the soil showed no significant differences (Tukey post-hoc test, 95\% confidence level). For both soils, slight increases in sorption were observed until the equilibrium plateau was reached after $8 \mathrm{~h}$ of stirring (apparent equilibrium).

The equilibrium time was shorter than reported by Li et al. (2004) for four Chinese soils originating from rice crop fields, where it was found that the $\mathrm{CMZ}$ sorption processes reached equilibrium after $24 \mathrm{~h}$.

The results obtained for the kinetics of CMZ sorption (Table IV) showed that the pseudo-second order kinetic model presented the best fit to the experimental data, based on the coefficient of determination $\left(\mathrm{R}^{2}>0.99\right)$. This indicated that the sorption kinetics was entirely controlled by sorption/ desorption processes and that it was governed by the availability of sorption sites on the soil (or the soil amended with biochar) surface, rather than by the concentration of CMZ in the solution (Liu 2008, Plazinski et al. 2009). The $q_{\theta}$ values provided by the kinetic model revealed a notable 


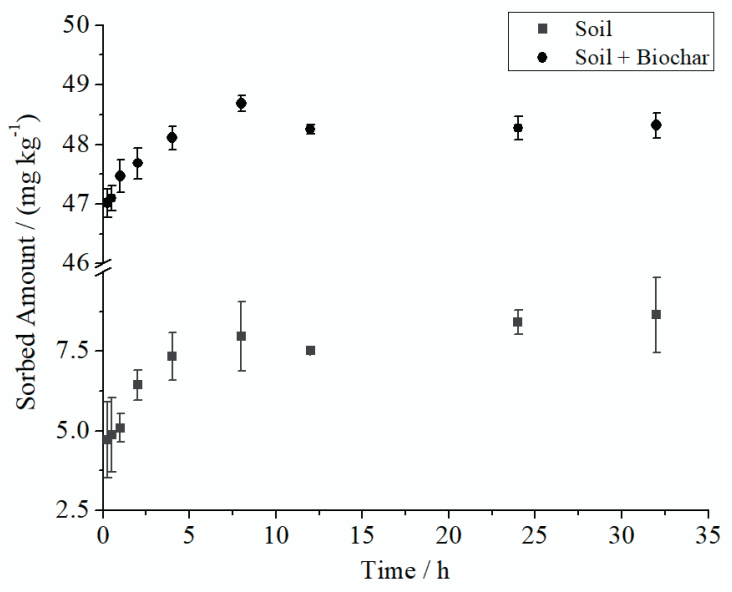

Figure 2 - Amount of $\mathrm{CMZ}\left(\mathrm{mg} \mathrm{kg}^{-1}\right)$ sorbed into $2 \mathrm{~g}$ of soil amended with $1 \%$ biochar in particle size $<106 \mu \mathrm{m}(\bullet$ Soil + Biochar) and into $2 \mathrm{~g}$ of pure soil (匹 Soil), after contact with an herbicide solution $\left(10 \mathrm{mg} \mathrm{L}^{-1}\right)$ in function of time stirring.

increase of the soil sorption capacity following the addition of biochar. According to Wang and Xing (2007), pyrolysis results in changes in the surface chemical groups, as well as the formation of new micropores in the biomass. Consequently, the addition of biochar to soils results in increased sorption capacity, due to its high surface area, high porosity, and the presence of aromatic components in its matrix.

\section{EFFECTS OF BIOCHAR PARTICLE SIZE AND PERCENTAGE ON CMZ SORPTION IN SOIL}

The effects of biochar particle size and biochar/soil percentage on $\mathrm{CMZ}$ sorption in soil were evaluated using a $2^{2}$ factorial design with a central point. The results, in terms of the apparent sorption coefficient $\left(K_{\mathrm{d}}^{\text {sor }}\right)$, are shown in Table V.

The effects of the factors on the CMZ sorption on soil (Figure 3) showed that both particle size (negative effect) and percentage (positive effect) of the biochar were significant (at the $95 \%$ confidence level). In other words, a smaller particle size and higher biochar percentage helped increase sorption of the herbicide in the soil. The curvature and the interaction between the factors were also significant.

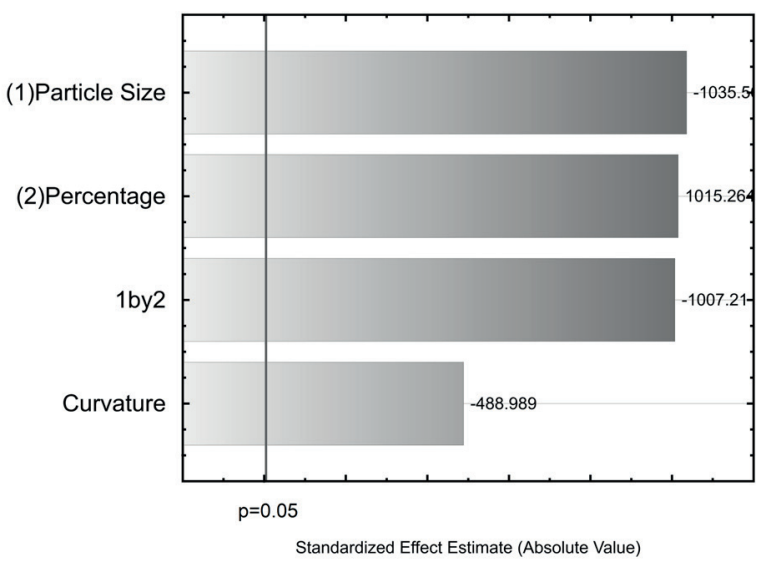

Figure 3 - Pareto chart of the standardized effects of factors particle size (1) and percentage biochar/soil (2) for CMZ sorption evaluation.

The biochar particle size and percentage used in experiment E3 provided the highest sorption of CMZ in soil, based on the $K_{\mathrm{d}}^{\text {sor }}$ values shown in Table $\mathrm{V}\left(K_{\mathrm{d}}^{\text {sor }}=616\right)$. It could therefore be concluded that the conditions that favored greater sorption, in the range of particle sizes and percentages studied, were the highest percentage (1\%) and the smallest particle size $(<106 \mu \mathrm{m})$.

In the absence of biochar $\left(\boldsymbol{K}_{\mathrm{d}}^{\text {sor }}=0.47\right)$, the partitioning of $\mathrm{CMZ}$ between the aqueous solution and the soil was lower than in all the experiments with biochar addition (Table V). Comparison of the sorption capacities of the unmodified (without addition of biochar) and amended soils showed that addition of the pyrogenic material increased the $\boldsymbol{K}_{d}^{\text {sor }}$ value by up to 1300 -fold (experiment E3). The relative contributions of the biochar to the increase sorption were 95.3, 70.6, 99.9, 88.3, and $88.9 \%$ for experiments E1, E2, E3, E4, and E5, respectively, showing that the biochar provided more effective sorption, compared to the other soil fractions. Similar results were obtained by Yu et al. (2011), who showed that the addition of $0.5 \%$ eucalyptus biochar increased the sorption of acetamiprid insecticide in three different soils, and that the relative contribution of biochar to the 
TABLE IV

Parameters obtained in the sorption kinetics of CMZ in soils amended $(\mathrm{S}+\mathrm{B})$ and without the addition of biochar (S).

\begin{tabular}{|c|c|c|c|c|c|c|c|c|c|}
\hline \multirow[t]{2}{*}{ Soil } & \multicolumn{3}{|c|}{ Pseudo-first order } & \multicolumn{3}{|c|}{ Pseudo-second order } & \multicolumn{3}{|c|}{ Elovich } \\
\hline & $q_{e}\left(m g k g^{-1}\right)$ & $k_{1}\left(h^{-1}\right)$ & $R^{2}$ & $q_{e}\left(m g k g^{-1}\right)$ & $k_{2}\left(k g m g^{-1} h^{-1}\right)$ & $R^{2}$ & $1 / Y \ln (X Y)\left(m g k g^{-1}\right)$ & $1 / Y\left(k g m g^{-1} h^{-1}\right)$ & $R^{2}$ \\
\hline $\mathrm{S}$ & 7.611 & 2.091 & 0.450 & 8.693 & 0.163 & 0.998 & 5.675 & 0.883 & 0.941 \\
\hline $\mathrm{S}+\mathrm{B}$ & 47.992 & 15.434 & 0.259 & 48.333 & 2.540 & 0.999 & 47.488 & 0.312 & 0.802 \\
\hline
\end{tabular}

TABLE V

Responses obtained in the experiments of the factorial design and in soil pure in terms of the apparent sorption coefficient.

\begin{tabular}{|c|c|c|c|c|c|}
\hline \multirow[b]{2}{*}{ Experiments } & \multicolumn{2}{|c|}{ Encoded factors } & \multicolumn{3}{|c|}{ Responses } \\
\hline & $\begin{array}{c}\text { Particle Size (1) } \\
\qquad /(\mu \mathrm{m})\end{array}$ & $\begin{array}{c}\text { Percentage (2) } \\
/(\%) \\
\end{array}$ & $K_{\mathrm{d}}^{\text {sor }} /\left(\mathrm{L} \mathrm{kg}^{-1}\right)$ & $K_{\mathrm{d}}^{\mathrm{des}} /\left(\mathrm{L} \mathrm{kg}^{-1}\right)$ & $\begin{array}{c}\text { Percentage Desorbed } \\
/(\%)\end{array}$ \\
\hline E1 & $<106$ & 0.25 & 10.1 & 31.5 & 13.7 \\
\hline E2 & $610-508$ & 0.25 & 1.6 & 4.0 & 55.4 \\
\hline E3 & $<106$ & 1 & 616.3 & $*$ & $*$ \\
\hline E4 & $610-508$ & 1 & 4.0 & 15.0 & 25.0 \\
\hline E5 & $508-106$ & 0.5 & $4.22 \pm 0.24$ & $12.9 \pm 1.2$ & $28.0 \pm 1.9$ \\
\hline SOIL & & & $0.47 \pm 0.02$ & $* *$ & $100 * *$ \\
\hline
\end{tabular}

E1 - Soil amended with $0.25 \%$ of biochar in particle size $<106 \mu \mathrm{m}$.

E2 - Soil amended with $0.25 \%$ of biochar in particle size between 508-610 $\mu \mathrm{m}$.

E3 - Soil amended with $1 \%$ of biochar in particle size $<106 \mu \mathrm{m}$.

E4 - Soil amended with $1 \%$ of biochar in particle size between $508-610 \mu \mathrm{m}$.

E5 - Soil amended with $0.5 \%$ of biochar in particle size between 106-508 $\mu \mathrm{m}$.

SOIL - Soil without addition of biochar.

$K_{\mathrm{d}}^{\text {sor }}$ - Apparent sorption coefficient, after contact of the soil (amended or without biochar) sample, with a CMZ solution (10 mg $\mathrm{L}^{-1}$ ) and under stirring for $8 \mathrm{~h}$.

$K_{\mathrm{d}}^{\text {des }}-$ Apparent desorption coefficient, after contact of the soil samples (obtained at the end the sorption assay) with a $\mathrm{CaCl}_{2}$ and $\mathrm{NaN}_{3}$ solution (free of CMZ) and under stirring for $8 \mathrm{~h}$.

* In this experiment it was not possible to quantify the CMZ in aqueous solution due to its concentration was below the analytical concentration range assessed in this work.

** In this experiment all CMZ was desorbed.

sorption varied according to the quantity of organic matter present in the soil.

In the work of Zheng et al. (2010), it was shown that smaller particle sizes of biochar resulted in lower availability of the herbicide atrazine in aqueous solutions, as well as shorter times to reach equilibrium sorption of the herbicide by the biochar. Similar features were observed here for CMZ (Table V), with greater sorption of the herbicide by the smaller particle size biochar, and enhancement of the effect with increasing percentage of biochar in the soil.
The results of the desorption assays showed that the soils modified with biochars presented lower extractions (using aqueous $\mathrm{CaCl}_{2}$ and $\mathrm{NaN}_{3}$ solution) of CMZ initially retained in the soil, compared to the unmodified soil, which showed complete desorption of CMZ by the aqueous solution. It was observed that the particle size factor also contributed to lower extraction. In experiments E2, E4, and E5, with larger particle size biochars, the herbicide concentrations in the soils were 4.0, 15.0, and 12.9 times higher (based on $\boldsymbol{K}_{\mathrm{d}}^{\text {des }}$ values), respectively, than the concentrations of herbicide 
in the aqueous solutions. In experiment E1, using biochar with smaller granulometry, the retention was even higher and the $\mathrm{CMZ}$ concentration in the solid phase was 31.5 times greater than in solution, confirming the important contribution of surface area in determining the sorption capacity of the biochar.

An increase in the biochar percentage also led to a greater amount of herbicide retained in the soil, as shown by comparison of the ${ }^{K_{\mathrm{d}}^{\text {des }}}$ values obtained in experiments E2 and E4. The same effect could be seen for comparison of experiments E1 and E3, although the amount of herbicide extracted by the aqueous solution in experiment E3 was so small that its quantification was not possible. This could be explained by the high relative contribution of the biochar to CMZ sorption in this experiment, providing further evidence of the strength of the interaction between the herbicide and the biochar.

\section{SORPTION AND DESORPTION ISOTHERMS}

In order to improve understanding of the CMZ sorption mechanisms, sorption and desorption isotherms were obtained for the factorial design experiments and the assay using unmodified soil. The CMZ concentration range employed in the isotherms was between 10 and $20 \mathrm{mg} \mathrm{L}^{-1}$. This high concentration range was selected because at lower CMZ concentrations (in preliminary tests), conditioning of the soil using the smaller particle size biochar resulted in sorption of all the $\mathrm{CMZ}$ present in the aqueous solution, making its quantification by HPLC impossible.

The sorption and desorption isotherms obtained are shown in Figure 4, together with the curve obtained using the Freundlich equation to fit the data. The Freundlich equation provided statistically significant explanations of the sorption and desorption processes in all the experiments (from the factorial design and using unmodified soil), with $p$-values $<0.01$. The parameters obtained for each model are shown in Table VI.

The sorption isotherms obtained for the SOIL (unmodified soil) and E2 (soil amended using $0.25 \%$ of biochar with particle size of 508-610 $\mu \mathrm{m})$ experiments presented the highest $1 / \mathrm{n}$ values, which were close to unity, so they were classified as type C. This type of isotherm indicated a constant affinity between the CMZ molecules and the sorption sites present in the adsorbent (Giles et al. 1974, McBride 1994).

A decrease in biochar particle size and/or an increase in the biochar percentage led to a decrease of the $1 / \mathrm{n}$ parameter and alteration of the sorption behavior. In experiments E1 (soil amended using $0.25 \%$ of biochar with particle size $<106 \mu \mathrm{m}$ ), E4 (soil amended using 1\% of biochar with particle size 508-610 $\mu \mathrm{m}$ ), and E5 (soil amended using $0.5 \%$ of biochar with particle size $106-508 \mu \mathrm{m}$ ), the curves obtained could be classified as type L. These isotherms suggested high affinity (early during the sorption process) between the herbicide and the soil amended with biochar. The sorption isotherm for experiment E3 (obtained for soil amended using 1\% of biochar with particle size $<106 \mu \mathrm{m}$ ) represented an extreme case of this classification, with the lowest $1 / \mathrm{n}$ value, and could be considered a type $\mathrm{H}$ isotherm. This isotherm type was indicative of stronger interactions between the $\mathrm{CMZ}$ molecules and the soil amended with biochar (McBride 1994).

The sorption behavior of CMZ in the soil was altered following the addition of biochar, and was also influenced by the characteristics of the biochar (particle size and percentage). This was demonstrated by the changes in the $1 / \mathrm{n}$ parameter (Table VI) and the type of isotherm when the biochar particle size was decreased and the biochar percentage was increased.

According to MacKay and Vasudevan (2012), another way of predicting the sorption behavior of polyfunctional organic compounds in environmental solids is by evaluating the types of 

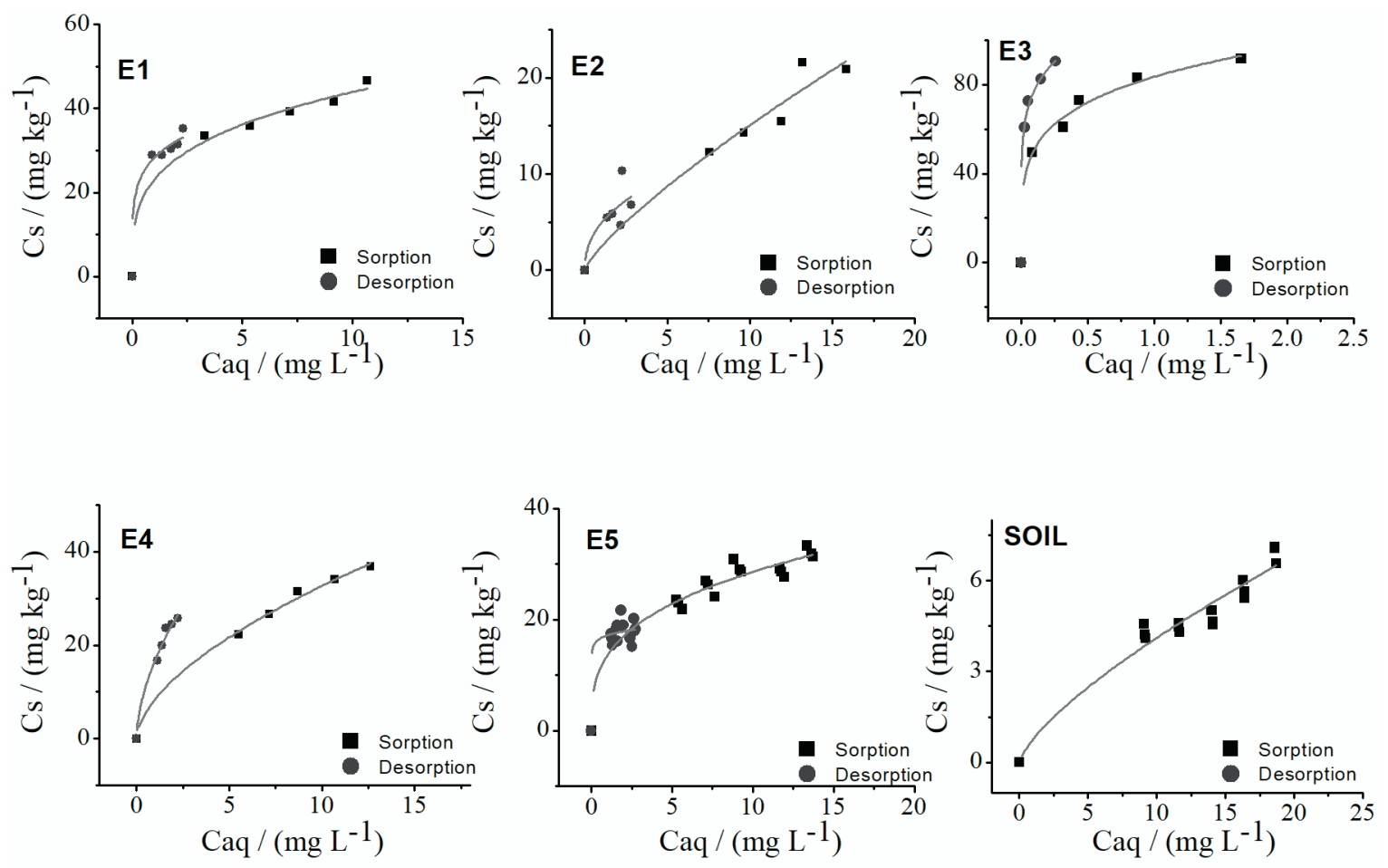

Figure 4 - Isotherms obtained in the CMZ sorption and desorption assays in a Red Latosol amended with different particle sizes and percentages of biochar (E1: soil amended with $0.25 \%$ of biochar in particle size < $106 \mu \mathrm{m}$; E2: soil amended with $0.25 \%$ of biochar in particle size between 508-610 $\mu \mathrm{m}$; E3: soil amended with $1 \%$ of biochar in particle size $<106 \mu \mathrm{m}$; E4: soil amended with $1 \%$ of biochar in particle size between $508-610 \mu \mathrm{m}$ and E5: soil amended with $0.5 \%$ of biochar in particle size between 106-508 $\mu \mathrm{m}$ ) and without addition of the sorbent (SOIL).

TABLE VI

Parameters of Freundlich isotherms $\left(K_{f}\right.$ and $\left.1 / n\right)$ and its coefficients of determination.

\begin{tabular}{|c|c|c|c|c|c|}
\hline \multirow[t]{2}{*}{ Experiment } & \multirow{2}{*}{$\begin{array}{c}\text { Phenomenon } \\
\text { studied }\end{array}$} & \multicolumn{4}{|l|}{ Freundlich } \\
\hline & & $K_{\mathrm{f}}\left(\mu \mathrm{g}^{1-1 / \mathrm{n}}\left(\mathrm{cm}^{-3}\right)^{1 / \mathrm{n}} \mathrm{g}^{-1}\right)$ & $1 / n$ & $\mathbf{R}^{2}$ & p-value \\
\hline \multirow[t]{2}{*}{ E1 } & Sor* & 23.0219 & 0.2806 & 0.8934 & $1.7238 \times 10^{-6}$ \\
\hline & Des** & 28.2427 & 0.1893 & 0.5530 & $4.9229 \times 10^{-6}$ \\
\hline \multirow[t]{2}{*}{ E2 } & Sor* & 2.4292 & 0.7934 & 0.7575 & $1.0115 \times 10^{-4}$ \\
\hline & $\operatorname{Des}^{* *}$ & 4.8916 & 0.4319 & -0.1497 & 0.00656 \\
\hline \multirow[t]{2}{*}{ E3 } & Sor* & 83.4806 & 0.2126 & 0.9606 & $2.3583 \times 10^{-6}$ \\
\hline & Des** & 112.8474 & 0.1618 & 0.9635 & $1.3409 \times 10^{-5}$ \\
\hline \multirow[t]{2}{*}{ E4 } & Sor* & 8.4023 & 0.5900 & 0.9733 & $4.9290 \times 10^{-7}$ \\
\hline & Des** $^{* *}$ & 16.7875 & 0.5753 & 0.8587 & $8.1121 \times 10^{-6}$ \\
\hline \multirow[t]{2}{*}{ E5 } & Sor* & 13.6423 & 0.3216 & 0.7547 & $1.1102 \times 10^{-16}$ \\
\hline & Des** & 17.1957 & 0.0583 & -0.0472 & $1.2845 \times 10^{-13}$ \\
\hline SOIL & Sor* & 0.7657 & 0.7302 & 0.7881 & $2.0872 \times 10^{-14}$ \\
\hline
\end{tabular}

*Sorption and **Desorption. 
interactions between these compounds and the sites present on the surfaces of solids. These interactions were classified as type I (hydrophobic partitioning and electron donor-acceptor interactions) and type II (interactions involving ion exchange, surface complexation, and cation bridges).

$\mathrm{CMZ}$ is a non-ionic polyfunctional compound whose structure includes regions with high electron density, such as the aromatic part and the isoxazolidinone group. These enable electron donor interactions with neutral species (with low electron density) such as metal oxides and surface aluminosilicate groups. Due to the presence of nitrogen and oxygen atoms in the isoxazolidinone group, hydrogen bonds can also be formed with the hydroxyl groups present in organic matter, and complexes can be formed with surface aluminum and iron atoms (MacKay and Vasudevan 2012).

Like graphite, the structure of biochars includes disorderly stacked polyaromatic sheets, which form highly sorptive aromatic $\pi$-systems. These aromatic structures have the ability to perform $\pi$-donor and $\pi$-acceptor interactions, depending on the substituent groups attached to aromatic rings of compounds to be sorbed. In the case of sorption of $\pi$-acceptor compounds (which have deactivating groups on the aromatic ring), both hydrophobic van der Waals interactions and hydrogen bonding are possible mechanisms that can provide strong sorption. In the case of $\pi$-donor compounds (which have activating groups present on the aromatic ring), such as CMZ, van der Waals and $\pi-\pi$ interactions are possible mechanisms of adsorption, with their intensities increasing according to the number of aromatic rings present and the planarity of the molecule (Keiluweit and Kleber 2009). These features suggest that the sorption of CMZ in the soil (and in soil amended with biochar) followed a type I mechanism governed by hydrophobic partitioning mechanisms and electron donor-acceptor interactions (MacKay and Vasudevan 2012).
CORRELATION BETWEEN A $\mathrm{t}_{\text {tot.biochar }}$ AND
PARAMETERS $\mathrm{K}_{\mathrm{f}}$ AND $1 / \mathrm{n}$

The Freundlich isotherm $\mathrm{K}_{\mathrm{f}}$ and $1 / \mathrm{n}$ parameters obtained in the sorption and desorption assays were correlated with the $\%$ biochar/d ratio, which is proportional to the total external surface area of the biochar $\left(A_{\text {tot.biochar }}\right)$. The results of these correlations and the parameters obtained in the linear regressions are shown in Figure 5 and Table VII, respectively.

The values of $K_{\mathrm{f}}^{\text {sor }}$ and $K_{\mathrm{f}}^{\text {des }}$ were highly correlated with the \% biochar/d ratio $(\mathrm{R}>0.99, \mathrm{p}$ $<0.0001$ ), showing that the processes of sorption and desorption of $\mathrm{CMZ}$ on the amended soil were directly influenced by the total external surface area of the biochar present in it. An increase in biochar surface area implies an increase in the number of sorption sites that enable hydrophobic partitioning, electron donor-acceptor interactions, and hydrogen bonding (Wang et al. 2016), providing higher sorption (higher $K_{\mathrm{f}}^{\text {sor }}$ ) and lower desorption (higher $K_{\mathrm{f}}^{\text {des }}$ ) of CMZ in soil. The $1 / \mathrm{n}_{\text {ads }}$ and $1 / \mathrm{n}_{\text {des }}$ parameters showed poor correlations with the $\%$ biochar/d ratio $(\mathrm{R}<0.62, \mathrm{p}>0.05)$, although there was a downward trend of these parameters with increasing \% biochar/d ratio. This inverse behavior could be attributed to increased aromatic domains in the soil, due to a greater total surface area of the biochar, contributing to nonlinearity of the isotherms and change in the sorption mechanisms (Wang et al. 2016, Zhu et al. 2004).

\section{EFFECT OF BIOCHAR ADDITION ON SOIL PHYSICOCHEMICAL PROPERTIES}

Assessment of changes in the properties of the soil was carried out by comparing the physicochemical characteristics of unmodified soil and the soil amended with biochar that provided the greatest $\mathrm{CMZ}$ sorption, determined in the factorial design experiments (Table II).

The results showed that the addition of sugarcane biochar to soil increased the 

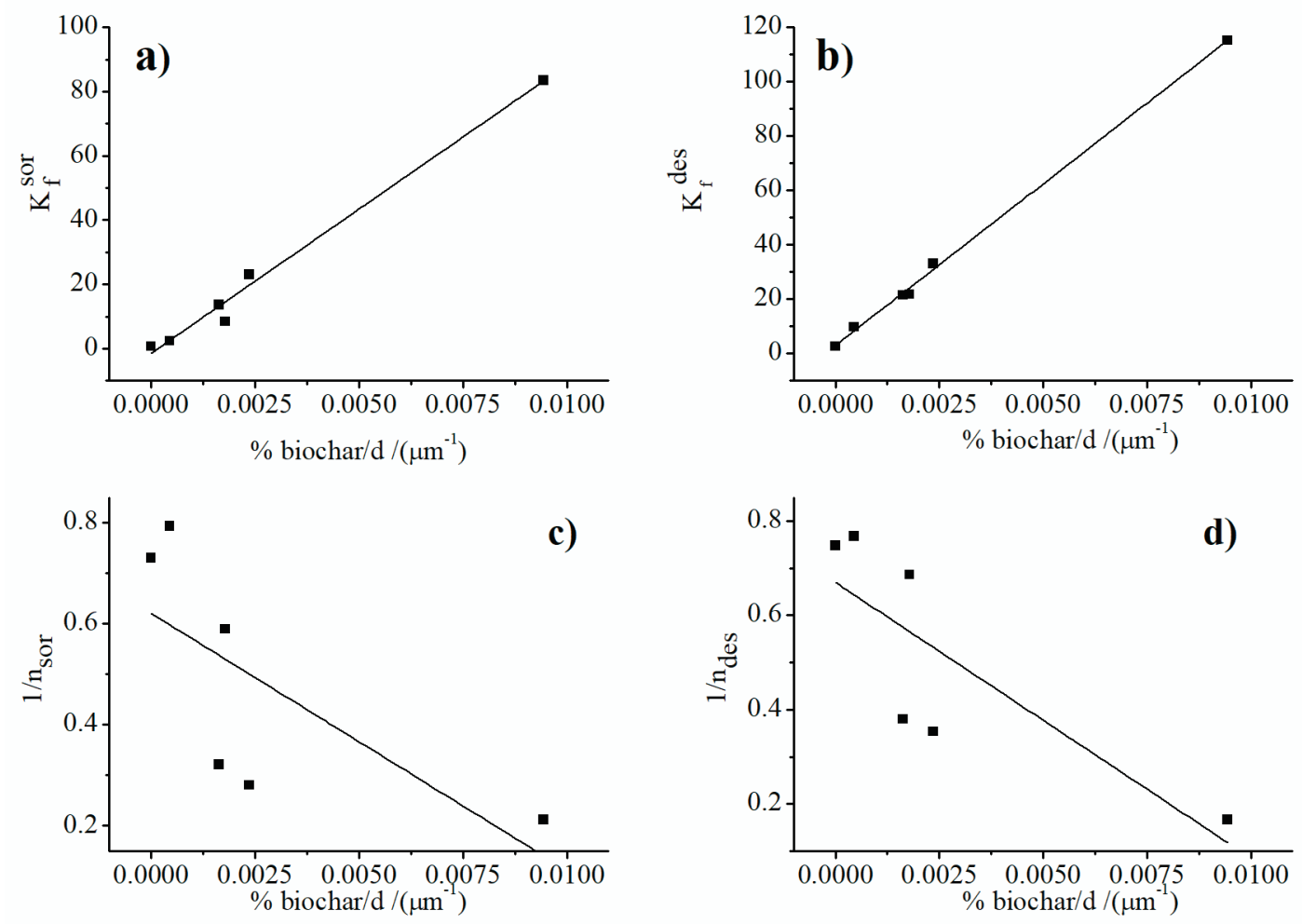

Figure 5 - Evaluation of the influence of the total external surface area of biochar on the sorption and dessorption of CMZ by the correlation of ratio $\%$ biochar/d with the parameters of the Freundlich equation $\boldsymbol{K}_{\mathrm{f}}^{\text {sor }}(\mathbf{a}) \boldsymbol{K}_{\mathrm{f}}^{\text {des }}(\mathbf{b})$ $1 / \mathrm{n}_{\text {sor }}(\mathbf{c})$ and $1 / \mathrm{n}_{\text {des }}(\mathbf{d})$.

TABLE VII

Parameter values obtained from the correlation between the ratio $\%$ biochar/d and parameters of Freundlich equation $K_{\mathrm{f}}^{\text {sor }}, K_{\mathrm{f}}^{\text {des }}, 1 / \mathbf{n}_{\text {sor }}$ and $1 / \mathbf{n}_{\text {des }}$.

\begin{tabular}{lcc}
\hline & Correlation & R \\
\hline$\%$ Biochar/d vs $K_{\mathrm{f}}^{\text {sor }}$ & $8976.40(\%$ Biochar $/ \mathrm{d})-1.46731$ & 0.9930 \\
$\%$ Biochar/d vs $K_{\mathrm{f}}^{\text {des }}$ & $12171.80(\%$ Biochar $/ \mathrm{d})-2.1224$ & 0.9985 \\
$\%$ Biochar $/ \mathrm{d}$ vs $1 / \mathrm{n}_{\text {sor }}$ & $-50.87748(\%$ Biochar $/ \mathrm{d})+0.62083$ & 0.6132 \\
$\%$ Biochar $/ \mathrm{d}$ vs $1 / \mathrm{n}_{\text {des }}$ & $-22.2132(\%$ Biochar $/ \mathrm{d})+0.35288$ & 0.3745 \\
\hline
\end{tabular}

concentrations of $\mathrm{P}, \mathrm{K}$, and $\mathrm{Mg}$ in the soil by $0.8 \mathrm{mg}$ $\mathrm{kg}^{-1}, 105 \mathrm{mg} \mathrm{kg}^{-1}$, and $0.8 \mathrm{mmol} \mathrm{kg}^{-1}$, respectively. These results indicate that the material has potential to act as a fertilizer. In addition, biochar improved the values for $\mathrm{CEC}, \mathrm{OM}$, and $\mathrm{pH}$, which are important factors affecting the sorption processes of nutrients and organic compounds in soil. These findings were in agreement with the review provided by Glaser et al. (2002), who reported that the addition of biochar to soil had the combined effects of increasing the organic matter content, improving the retention and availability of nutrients, increasing the cation exchange capacity (CEC), and altering the $\mathrm{pH}$. 


\section{ACKNOWLEDGMENTS}

This research was financially supported by the Brazilians Agencies: Conselho Nacional de Desenvolvimento Científico e Tecnológico (CNPq), Fundação de Amparo à Pesquisa do Estado de Minas Gerais (FAPEMIG) and Coordenação de Aperfeiçoamento de Pessoal de Nível Superior (CAPES).

\section{REFERENCES}

ANVISA. 2003. Resolução RE n ${ }^{\circ}$ 899, de 29 de maio de 2003. ANVISA. 2017. Resolução da diretoria colegiada $n^{\circ} 166$, de 24 de julho de 2017.

BENITES VM, TEIXEIRA WG, REZENDE ME AND PIMENTA AS. 2009. Utilização de carvão e subprodutos da carbonização vegetal na agricultura: aprendendo com as terras pretas de índio. In: As terras pretas de índio da Amazônia: sua caracterização e uso deste conhecimento na criação de novas áreas. Embrapa Amazônia Ocidental, Manaus, AM, p. 420.

EMBRAPA. 1997. Manual de Métodos de Análise de Solo. Empresa Brasileira de Pesquisa Agropecuária, Rio de Janeiro, RJ.

FERNÁNDEZ-BAYO JD, NOGALES R AND ROMERO E. 2008. Evaluation of the sorption process for imidacloprid and diuron in eight agricultural soils from Southern Europe using various kinetic models. J Agric Food Chem 56: 5266-5272.

GILES CH, SMITH D AND HUITSON A. 1974. A general treatment and classification of the solute adsorption isotherm. I. Theoretical. J Colloid Interface Sci 47: 755765.

GLASER B AND BIRK JJ. 2012. State of the scientific knowledge on properties and genesis of Anthropogenic Dark Earths in Central Amazonia (terra preta de Índio). Geochim Cosmochim Acta 82: 39-51.

GLASER B, LEHMANN J AND ZECH W. 2002. Ameliorating physical and chemical properties of highly weathered soils in the tropics with charcoal - a review. Biol Fertil Soils 35: 219-230.

IPEA. 2012. Diagnóstico dos Resíduos Orgânicos do Setor Agrossilvopastoril e Agroindústrias Associadas.

IUPAC. 2007. Pesticide Properties Database [WWW Document]. Int. Union Pure Appl. URL http://sitem.herts. ac.uk/aeru/iupac/Reports/168.htm (Accessed on January 31, 2017).

JANOS P, MICHALEK P AND TUREK L. 2007. Sorption of ionic dyes onto untreated low-rank coal - oxihumolite: A kinetic study. Dye Pigment 74: 363-370.
KEILUWEIT M AND KLEBER M. 2009. Molecular-level interactions in soils and sediments: The role of aromatic $\pi$-systems. Environ Sci Technol 43: 3421-3429.

LI L, LI G, YANG R, GUO Z AND LIAO X. 2004. Clomazone dissipation, adsorption and translocation in four paddy topsoils. J Environ Sci 16: 678-682.

LIU Y. 2008. New insights into pseudo-second-order kinetic equation for adsorption. Colloids Surf A Physicochem Eng Asp 320: 275-278.

MACKAY AA AND VASUDEVAN D. 2012. Polyfunctional ionogenic compound sorption: challenges and new approaches to advance predictive models. Environ Sci Technol 46: 9209-9223.

MAPA. 2013. Agrofit [WWW Document]. Ministério da Agric. Pecuária e Abast. URL http://extranet.agricultura. gov.br/agrofit_cons/principal_agrofit_cons (Accessed on January 31, 2017).

MCBRIDE MB. 1994. Organic Polluants in Soils In: Enviromental Chemistry of Soils. Oxford University Press, New York, NY, p. 406.

OECD. 2000. Adsorption - Desorption Using a Batch Equilibrium Method. Oecd Guidel Test Chem, p. 1-44.

PAPELIS C, UM W, RUSSELL CE AND CHAPMAN JB. 2003. Measuring the specific surface area of natural and manmade glasses: Effects of formation process, morphology, and particle size. Colloids Surf A Physicochem Eng Asp 215: 221-239.

PERUCHI LM, FOSTIER AH AND RATH S. 2015. Sorption of norfloxacin in soils: Analytical method, kinetics and Freundlich isotherms. Chemosphere 119: 310-317.

PETTER FA AND MADARI BE. 2012. Biochar: Agronomic and environmental potential in Brazilian savannah soils. Rev Bras Eng Agríc Ambient 16: 761-768.

PLAZINSKI W, RUDZINSKI W AND PLAZINSKA A. 2009. Theoretical models of sorption kinetics including a surface reaction mechanism: A review. Adv Colloid Interface Sci 152: 2-13.

QIU H, LV L, PAN B, ZHANG QQ, ZHANG W AND ZHANG QQ. 2009. Critical review in adsorption kinetic models. J Zhejiang Univ Sci A 10: 716-724.

RITTL TF, ARTS B AND KUYPER TW. 2015. Biochar: An emerging policy arrangement in Brazil? Environ Sci Policy 51: 45-55.

SCHMIDT MJ ET AL. 2014. Dark earths and the human built landscape in Amazonia: A widespread pattern of anthrosol formation. J Archaeol Sci 42: 152-165.

SCHMUKAT A, DUESTER L, ECKER D, SCHMID H, HEIL C, HEININGER P AND TERNES TA. 2012. Leaching of metal(loid)s from a construction material : Influence of the particle size, specific surface area and ionic strength. J Hazard Mater 227-228: 257-264.

SCORZA JÚNIOR RP. 2009. Estudos Sobre o Comportamento Ambiental de Agrotóxicos em Áreas com Cana-de- 
açúcar. [WWW Document]. Artig. Especiais, Portal DIAdeCAMPO. URL http://www.diadecampo.com.br/ zpublisher/materias/Materia.asp?id=20720\&s (Accessed on January 31, 2017).

SILVA AA, VIVIAN R AND OLIVEIRA JÚNIOR SR. 2007.

Herbicidas: Comportamento no Solo. In: Tópicos Em Manejo Integrado de Plantas Daninhas. Editora UFV, Viçosa, MG, p. 155-209.

SINDIVEG. 2015. Dados de produção e consumo de agrotóxicos, 2015 [WWW Document]. Sind. Nac. das Indústrias Defensivos Agrícolas. URL http://sindiveg.org. br/ (Accessed on February 26, 2016).

SONG Y, WANG F, BIAN Y, KENGARA FO, JIA M, XIE Z AND JIANG X. 2012. Bioavailability assessment of hexachlorobenzene in soil as affected by wheat straw biochar. J Hazard Mater 217-218: 391-397.

VAN SCOY AR AND TJEERDEMA RS. 2014. Environmental Fate and Toxicology of Clomazone. Rev Environ Contam Toxicol 229: 35-49.

WANG X AND XING B. 2007. Sorption of organic contaminants by biopolymer-derived chars. Environ Sci Technol 41: 8342-8348.

WANG Z, HAN L, SUN K, JIN J, RO KS, LIBRA JA, LIU X AND XING B. 2016. Sorption of four hydrophobic organic contaminants by biochars derived from maize straw, wood dust and swine manure at different pyrolytic temperatures. Chemosphere 144: 285-291.
WU C, ZHANG S, NIE G, ZHANG Z AND WANG J. 2011. Adsorption and desorption of herbicide monosulfuronester in Chinese soils. J Environ Sci 23: 1524-1532.

WU S, HE H, INTHAPANYA X AND YANG C. 2017. Role of biochar on composting of organic wastes and remediation of contaminated soils - a review. Environ Sci Pollut Res 24: 16560-16577.

XU T, LOU L, LUO L, CAO R, DUAN D AND CHEN Y. 2012. Effect of bamboo biochar on pentachlorophenol leachability and bioavailability in agricultural soil. Sci Total Environ 414: 727-731.

YU XY, MU CL, GU C, LIU C AND LIU XJ. 2011. Impact of woodchip biochar amendment on the sorption and dissipation of pesticide acetamiprid in agricultural soils. Chemosphere 85: 1284-1289.

ZHAO B, NAN X, XU H, ZHANG T AND MA F. 2017. Sulfate sorption on rape (Brassica campestris L.) straw biochar, loess soil and a biochar-soil mixture. J Environ Manage 201: 309-314.

ZHENG W, GUO M, CHOW T, BENNETT DN AND RAJAGOPALAN N. 2010. Sorption properties of greenwaste biochar for two triazine pesticides. J Hazard Mater 181: 121-126.

ZHU D, HYUN S, PIGNATELLO JJ AND LEE LS. 2004. Evidence for pi-pi electron donor-acceptor interactions between pi-donor aromatic compounds and pi-acceptor sites in soil organic matter through $\mathrm{pH}$ effects on sorption. Environ Sci Technol 38: 4361-4368. 